\title{
Intestinal Ascending Colon Morphometrics in Rats Submitted to Severe Protein Malnutrition
}

\author{
Morfometría de la Pared Intestinal del Colon Ascendente \\ de Ratas Sometidas a Desnutrición Proteica Severa) \\ Catchia Hermes; Jorge Fernandes de Azevedo; \\ Eduardo José de Almeida Araújo \& Débora de Mello Gonçales Sant’Ana
}

HERMES, C.; AZEVEDO, J. F.; ARAÚJO, E. J. A. \& SANT'ANA D. M. G. Intestinal ascending colon morphometrics in rats submitted to severe protein malnutrition. Int. J. Morphol., 26(1):5-11, 2008.

SUMMARY: This paper aims to verify the effects of severe protein malnutrition over the intestinal ascending colon morphometrics in adult rats. 12 rats (90 days old) were divided into 2 groups: control $(n=5)$ and malnutritioned $(n=7)$. In the following 90 days, the rats of the control group received a $24 \%$ protein chow as the malnourished group received $4 \%$ protein chow. The animals were submitted to euthanasia according to the anesthetic protocol. Colon segments were collected and submitted to routine histological processing. The cuts were stained with HE and histochemical techniques for mucines. The morphometric analyses showed the sustenance of the whole wall and muscle tunic thickness, as well as the reduction of the thickness of the mucosa tunic, the amount of goblet cells, the depth of the crypt and the height of the enterocytes as well as their nucleus on malnutritioned animals. The data suggest that protein malnutrition causes alterations on adult rat ascending colon intestinal morphometrics, especially in tissues which present a high level of cell turnover such as the mucosa tunic and consequently their structures such as the enterocytes, goblet cells, and crypts.

KEY WORDS: Hypoproteic Diet; Intestine; Intestinal Wall.

\section{INTRODUCTION}

The implications of malnutrition on different organs and body systems may be different according to the kind of organ and age. In the gut, protein malnutrition causes gastric and intestinal mucosa tunic atrophy, villous and microvillous decrease, of the intestinal traffic which may cause constipation, and diarrhea, in cases of compromising of the immunologic system (Waterlow, 1996).

Protein malnutrition experimental studies on different-age rat showed that the small intestine presents alterations demonstrated by the reduction of the intestinal wall layer thickness (Natali et al., 1995, 2000, 2005; Torrejais et al., 1995) as well as the reduction of the thickness of the mucosa tunic and enterocyte height (Brandão, 1998).

There are a few studies reporting the effects of protein malnutrition on the large intestine which despite of its minor nutrient absorption function, plays an important part on digestion, and most of all, absorption of water and electrolytes, fecal matter traffic, and production of fat-soluble vitamins. Firmansyah et al. (1989) demonstrated that malnutrition also compromises the development of the colon mucosa tunic and its crypts on animals during fetal development.

This study analyzed the effects of severe protein malnutrition on adult rat ascending intestinal wall colon morphometrics.

\section{MATERIAL AND METHOD}

The experimental protocol was previously approved by the Animal Research Ethics Committee of the Universidade Paranaense (UNIPAR).

This research received financial support from Universidade Paranaense (protocol 650/2004) and Fundação Araucária (convention 063/2004). It refers to the UNIPAR Pharmacy Graduation Final Paper of the first author. Experimental Neurogastroenterology Laboratory - Master's Degree in Animal Science. Universidade Paranaense - UNIPAR. Umuarama, Paraná, Brazil. 
Twelve Wistar male rats (Rattus norvegicus) 90 days old weighing $(304.64 \pm 28.06 \mathrm{~g})$ were kept in individual cages, in a room with controlled temperature $\left( \pm 25^{\circ} \mathrm{C}\right)$ and light/ dark cycles (12/12 h). During the whole period, water and chow were offered ad libitum. They were divided into 2 groups. The control group $(n=5)$ received NUVILAB ${ }^{\circledR}$ chow with $24 \%$ protein level for 90 days. The malnourished group $(n=7)$ received experimental chow presenting a $4 \%$ protein level, manipulated according to Araújo et al. (2005), for 90 days. The body weight of the animals was weekly assessed. After fasting for 12 hours, the animals were submitted to euthanasia according to the anesthetic protocol: Acepran $1.26 \mathrm{ml} / \mathrm{kg}$, Ketamina (10\%) $1.26 \mathrm{ml} / \mathrm{kg}$, Xilasina (2\%) $0.42 \mathrm{ml} / \mathrm{kg}$ e Atropina (1\%) $0.22 \mathrm{ml} / \mathrm{kg}$ (Pachaly et al., 2003) by intramuscular injection.

All animals had their ascending colon extracted, measured, weighed, then washed in saline solution, and fixed in a $10 \%$ buffered formalin in phosphate buffer $(\mathrm{pH} 7.3)$. The ascending colon segments were dehydrated in an ascending series of alcohol, diaphanized in xylol and paraffin-embedded for further 3 and $5 \mu \mathrm{m}$ transversal cuts stained with hematoxilin-eosin, Alcian Blue (AB, $\mathrm{pH} 2.5)$, and periodic acid Schiff (PAS).

The intestinal wall morphometric analysis was carried out from images captured using a Motic B5 optical microscope and digital camera (Moticam 2000, 2.0 M Pixel).

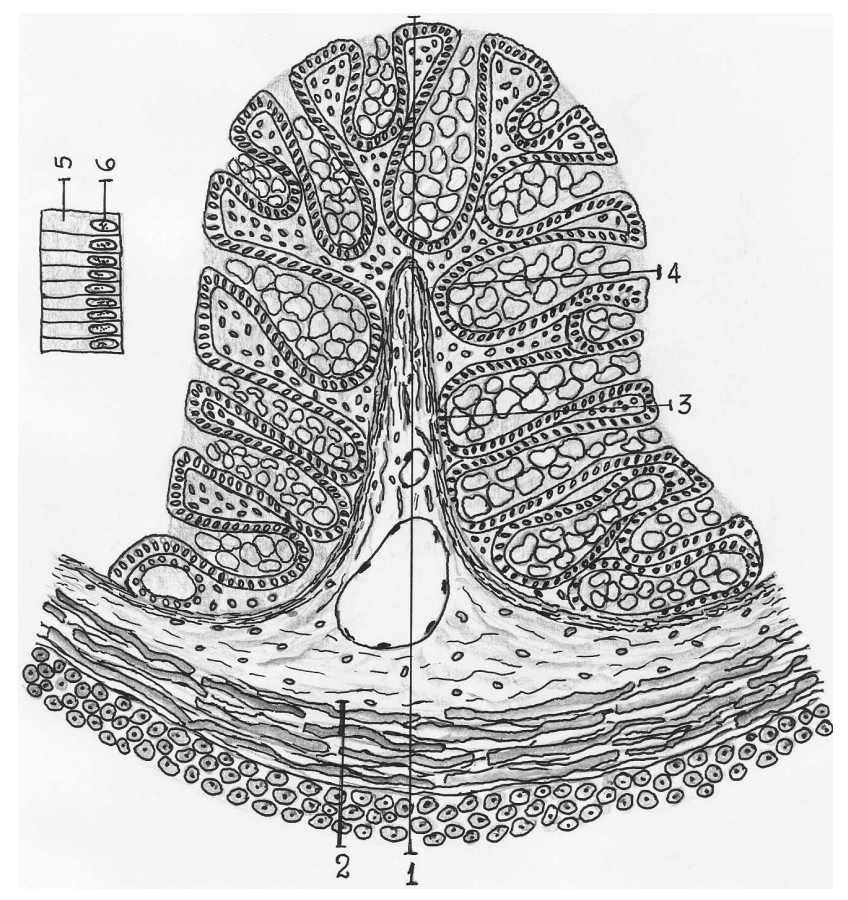

Fig. 1. Schematic representation evidencing the ascending colon of rats: 1 . Total wall; 2. Muscle tunic; 3. Mucosa tunic; 4. Depth of crypts; 5 . Enterocyte height and 6 . Nucleus of the enterocyt.
Images covering all intestinal circumferences were captured. 80 measurements were carried out over all intestinal circumferences of each rat, as 40 measurements were carried out over the crypts. Images captured with $4 x$ objective lense were used to measure the total thickness of the intestinal wall. The images captured with $20 x$ objective lense were used to measure the muscle tunic thickness, the thickness of the mucosa tunic, and the depth of the crypts. HE stained cuts were used for these measurements. Images from ABstained cuts were captured with 100x lenses in order to measure the nucleus largest diameter, as well as, the height of 960 enterocytes (only the ones presenting nucleolus). All measurements were carried out with Motic Images Plus 2.0.

Besides the measurements above, the goblet cells in $0.2 \mathrm{~mm}^{2}$ of the mucosa tunic of every animal were quantified. This quantification was carried out through stained cuts by $\mathrm{HE}, \mathrm{AB}$ ( $\mathrm{pH} 2.5$ ), and PAS. The account was carried out from images captured using a 40x objective lense.

All data was first submitted to the KolmogorovSmirnov Test in order to verify the distribution type. Data showing normal distribution are expressed as mean $\pm \mathrm{SD}$, the others are expressed as median (P25; P75). We used t-Test (normal distribution data) and Mann-Whitney (others distributions) in order to compare the control group and the malnourished group. $P$ values less than 0.05 was considered statistically significant in both cases.

\section{RESULTS}

The control group weighed $332.17 \pm 55.87 \mathrm{~g}$, as the malnourish group weighed $200.36 \pm 28.92 \mathrm{~g}$ by the end of the experiment. A significant reduction of $34.23 \%$ for the animal weight of the malnourish group was observed $(\mathrm{p}<0.0001)$.

The ascending colon for the malnourish group was smaller in relation to the control group, as presented in Table I.

The morphometric analysis did not present any significant difference occurrences for either the total wall thickness or the muscle tunic thickness for both groups, as well as a reduction of the thickness of the mucosa tunic, depth of the crypts, height of enterocytes and their nucleus height for the malnourished animals (Table II).

The quantification of the goblet cells by the HE, AB, and PAS techniques presented significant differences while comparing the control group and the malnourish group as shown in Table III. 
Table I. Length, width, area and weight of the ascending colon from rats of the control group and malnourished group.

\begin{tabular}{lcccc} 
Group & Length $(\mathrm{cm})$ & Width $(\mathrm{cm})$ & Area $\left(\mathrm{cm}^{2}\right)$ & Weight $(\mathrm{g})$ \\
Control $(\mathrm{n}=5)$ & $15.25 \pm 1.88^{*}$ & $1.56 \pm 0.22^{* * *}$ & $24.52 \pm 6.46^{* * *}$ & $2.55 \pm 0.47^{* * * *}$ \\
Malnourished $(\mathrm{n}=7)$ & $12.14 \pm 1.65^{*}$ & $1.20 \pm 0.33^{* *}$ & $14.71 \pm 4.56^{* * *}$ & $1.31 \pm 0.29^{* * * *}$ \\
\hline
\end{tabular}

$* \mathrm{p}=0.0015 ; * * \mathrm{p}=0.0263 ; * * * \mathrm{p}=0.0069 ; * * * * \mathrm{p}=0.0001$.

Table II. Total wall, muscle tunic and thickness of mucosa tunic, depths of the crypts, height of enterocytes and theirs nucleus for enterocyte of the ascending colons of rats from the control group and the malnourished group.

\begin{tabular}{lcc} 
Parameter & Control group & Malnourished group \\
\hline Total wall $(\mu \mathrm{m})$ & $1,215.82 \pm 183.25$ & $1,056.62 \pm 102.08$ \\
Muscle tunic $(\mu \mathrm{m})$ & $228.04 \pm 42.91$ & $204.99 \pm 56.07$ \\
Mucosa tunic $(\mu \mathrm{m})$ & $242.05(211.40 ; 273.00)^{* *}$ & $142.60(124.90 ; 163.60)^{* *}$ \\
Depth of crypts $(\mu \mathrm{m})$ & $141.45(124.90 ; 169.30)^{* *}$ & $76.70(54.35 ; 89.30)^{* *}$ \\
Enterocy te height $(\mu \mathrm{m})$ & $31.99 \pm 3.82^{*}$ & $26.01 \pm 4.15^{*}$ \\
Nucleus of the enterocytes $(\mu \mathrm{m})$ & $10.02 \pm 1.07^{*}$ & $7.95 \pm 1.18^{*}$
\end{tabular}

The total wall, muscle tunic, height of enterocytes and their nucleus are expressed as mean \pm sd. The thickness of the mucosa tunic and the depth of the crypts are expressed as median (P25; P75). *p $<0.01 ; * * \mathrm{p}<0.0001$.

Table III. Number of goblet cells in a $0.2 \mathrm{~mm}^{2}$ area of the ascending colon from rats of the control and malnourished groups evidenced by hematoxilin-eosine (HE), Alcian Blue (AB, $\mathrm{pH} 2.5)$, and periodic acid Schiff (PAS).

\begin{tabular}{llc} 
Technique & Control group & Malnouri shed group \\
\hline HE & $699.84 \pm 202.0^{*}$ & $403.51 \pm 54.3^{*}$ \\
AB $(\mathrm{pH} \mathrm{2.5)}$ & $538.44 \pm 95.95^{* *}$ & $359.25 \pm 39.12^{* *}$ \\
PAS & $136.36 \pm 25.54^{* * *}$ & $84.66 \pm 26.20^{* * *}$ \\
${ }^{*} \mathrm{p}=0.0037 ; * * \mathrm{p}=0.0011, * * * \mathrm{p}=0.0067$. &
\end{tabular}

\section{DISCUSSION}

The animals in this experiment, which were fed with $4 \%$ protein chow, presented less body weight gain as observed by several authors using different protein restriction models in young rats (Takano, 1964; Firmansyah \& Suharyono, 1969; Torrejais et al.; Natali \& Miranda-Neto, 1996; Sant'Ana et al., 1997; Brandão; Meilus et al., 1998; Fiorine et al., 1999; Natali et al., 2000; Zanim et al., 2003) thus demonstrating that the diet protein levels (for either quantity or quality) are essential for body weight gain during development. However, studies on old rats fed with a $8 \%$ protein diet did not present any body weight reduction, possibly because such animals present lower metabolic level and less protein intake would be enough for their sustenance (Natali et al., 2005; Schoffen et al., 2005).

The gut contributes for only $3-6 \%$ of the total body weight; however, it is the organ responsible for around 20 -
$35 \%$ of the protein turnover as well as the energy expenditure of the entire body (Lobley et al., 1980; McNurlan \& Garlick, 1980). Therefore, it is natural to have observed that the colon weight, length, width, and area in malnourished rats were significantly low what also was observed in protein-restricted experiments on the small intestine (Firmansyah \& Suharyono; Younoszai \& Ranshaw, 1973; Firmansyah et al.; Torrejais et al.; Natali \& Miranda-Neto; Meilus et al.; Natali et al., 2005) and rat colons (Firmansyah et al.; Sant'Ana et al., 1997 and 2001; Araújo et al., 2003). Deo (1978) states that malnutrition compromises the organ development, and Natali et al. (2005) considered that a smaller organ may be interpreted as an adaptive response to a smaller food intake.

While comparing other colon-related studies, we verified that the colon was $40 \%$ smaller in our control group, as it was $31.5 \%$ smaller in Sant'Ana et al. (1997). Such difference can be explained because the amount of protein $(8 \%)$ used in this study was doubled in relation to ours.

The ascending colon wall morphometric analysis showed muscle tunic thickness preservation in animals fed with $4 \%$ protein. This result is similar to Schoffen et al. who reduced the proteic level to $8 \%$ for old rats. Other authors observed muscle tunic thickness reduction (Torrejais et al.; Natali et al., 2000; 2005; Brandão et al., 2003), what may be assigned to not having proteic material accumulated on the cells of the muscle tunic (Schoffen et al.) since they were still growing animals. Natali et al. (1995), Torrejais et al. and Brandão (1998) demonstrated that the decreasing of the 
malnourished rat duodenal wall during pregnancy and lactation, which are critic periods for rat intestine development. Our results, as in Schoffen et al., showed no significant differences for that parameter, possibly, because in nutrient privation cases, the organism is forced to reorganize itself metabolically by selecting priorities for the distribution of the insufficient nutrients available for tissues and organs. For a possible recovering - aimed by any organism under privation - the tissues somehow injured did not heal homogeneously and synchronically, however, because of some tissue singularities, it is notorious that some tissues will reestablish quickly, such as, the connective and epithelial tissue whereas others slowly such as the muscle and nerve tissues. This may explain the muscle tunic sustenance in spite of the malnourished rat mucosa tunic observed in this study.

The mucosa tunic of the colon is substantially thicker due to the larger intestinal gland length in relation to the small intestine. Since there are not any villous, the surface of the mucosa tunic is smooth presenting an increasing number of goblet cells (Dellmann \& Brown, 1982). The reduction of the thickness of the mucosa tunic results from recurrent investigations analyzing the effects of the nutritional deficiencies over the intestinal morphometrics (Viteri \& Schneider, 1974; Rodrigues et al., 1985; Torrejais et al.; Brandão, 1998; Natali et al., 2000; Schoffen et al.). This might be explained by the fact that the mucosa tunic presents high regenerative capacity of its own tissues; therefore, less aminoacid intake would be assigned to low regenerative tissues in order to prevent permanent damage and to avoid the nitrogenic balance to become negative.

The depth of the crypts was smaller in malnourished animals in relation to the Control Group $(\mathrm{p}<0.05)$, as observed on the colon of rats by Firmansyah et al., and on the small intestine of rats by Brandão (1998). This decrease may possibly be related to the mucous reduction as the crypt is in the intestinal layer. As the crypts present basal cells capable of dividing several times by mitosis and differentiate amongst the number of intestine epithelium, our results suggest that the regeneration of such tissues was damaged.

The height of the enterocytes and their nucleus largest diameter was measured. The enterocyte is the epithelial cell of the intestinal mucosa tunic, which carries out the absorption, thus, its number will determine the epithelium absorption capacity (Brandão, 1998). Malnutrition may result in intestinal absorption decrease due to the enterocyte number and height decrease. The experimental malnourishment carried out in this study resulted in the reduction of the enterocyte height and their nucleus, as observed in rats feed with a protein-restricted diet by Brandão (1998). Pires et al.
(2003) did not find significant differences while analyzing the enterocyte height of children's small intestines; however, they pointed out to have found a disposition to the height decrease of such cells according to the increase of malnourishment levels, what is close to our findings since the diet proteic levels were $85 \%$ less than those for the control group in our experiment. As the colon is responsible for electrolyte and water absorption, malnutrition may be damaging this physiological function in the animals in this study, however, diarrhea was not observed.

Because of enterocyte height reduction, microorganism at the lumen may easily invade the organism through the transcellular pathway. Thus, reinforcement for the adhesion of these cells in order to prevent the attack through the paracellular pathway would be natural. Therefore, these cells would be strongly attached to each other through the cellular adhesion molecules. An immunohistochemical study with intra-uterine retardedgrowth rats submitted to protein malnourishment during pregnancy demonstrated an cadherin positive epithelial cell increase (probably enterocytes) in villous (Dalçik et al., 2003). These results may indicate more care regarding positioning, recognition, and epithelial cell unit coating the intestine of protein-deprived animals during pregnancy as a mechanism against adverse conditions.

When the goblet cells were quantified - in spite of the chemical nature of their content (HE stained cuts) - we verified they significantly decreased in the control group (around 42.34\%). Thus, we infer that the volume of the secreted by these cells (mucines) was smaller for the malnourished group, what may be understood as a way of endogen protein loss contention as well as the assignment of less aminoacid intake for cells, tissues, organs, and metabolic pathways essential for animal survival.

Mucines are related to both physiology and gastrointestinal health (Forstner \& Forstner, 1994). The proteic part of such molecules is mainly constituted by serine and presents binding sites for oligosaccharides, such as Nacetylgalactosamine, $\mathrm{N}$-acetylglucosamine, galactose, fucose and sialic acids. According to the carbohydrate composition, the mucines are classified in (1) neutral and the acid subtypes: sulphated and non-sulphated (3). The proportion amongst these classes may be influenced by the diet (Montagne et al., 2004).

The impact of protein in the diet over the composition of the mucines has not been largely studied. In this study, the number of PAS positive cells was smaller (37.9\%) as well as the AB ( $\mathrm{pH} 2.5$ ) positive cells (32.27\%) in the malnourished group. On the other hand, the proportion 
between acid and neutral mucous was 3.95 for the control group, whereas it was 4.24 for the malnourished group. This probably means that the ascending colon mucous in the animals of the malnourished group was less dense what might have influenced a higher interaction amongst lumen and microvillus molecules thus favoring nutrient absorption. On the other hand, this kind of mucous committees the mucous protection by favoring eruptions, as well as the increase the risk of lesions, ulcerations, and inflammatory diseases, what is important to be considered in relation to the intestinal lumen - an unfriendly environment to the colon. Turck et al. (1993) reported that the composition of the mucine in the colon of 21-day-old shoats milked naturally and artificially. The mucine from the shoats milked by female pigs presented more fucose and glycosamine and less sulphate, thus considered more mature than the mucines from animals artificially milked. It is worth to remark that quantitative and qualitative alterations concerning secretion, composition, and removing of intestinal lumen mucines may modify the defense barrier of the mucosa tunic as well as influence the colon's fermentation capacity what may result in important physiological implications (Smith \& Podolsky, 1986; Rhodes, 1989).

Intestinal growth and crypt increasing imply in the intestinal epithelial cell increasing and further absorption increase (Natali, 1993); therefore, our results demonstrated that the smaller growth for the organ with reduction of the mucosa area may result in the intestinal absorption damaging. The decrease of the crypt depth and the number of goblet cells has probably interfered in the normal functioning of the mucosa, its regeneration, and nutrient absorption, demonstrating that severe malnutrition reflects harmfully for the large intestine in adult animals.

\section{Acknowlegements}

The authors would like thank the financial support provided by Universidade Paranaense - UNIPAR and Fundação Araucária para o Desenvolvimento Científico e Tecnológico do Paraná.

HERMES, C.; AZEVEDO, J. F.; ARAÚJO, E. J. A. \& SANT'ANA D. M. G. Morfometría de la pared intestinal del colon ascendente de ratas sometidas a dsenutrición proteica severa. Int. J. Morphol., 26(1):5-11, 2008.

RESUMEN: El objetivo de este trabajo fue verificar los efectos de la desnutrición proteica severa sobre la morfometría de la pared intestinal del colon ascendente de ratas adultas. Fueron utilizadas 12 ratas (90 días de edad), divididas en dos grupos: control (n=5) y desnutrido (n=7). En los 90 días siguientes, las ratas del grupo control recibieron ración con $24 \%$ de contenido proteico y los del grupo desnutrido con 4\%. Los animales fueron eutanasiados de acuerdo al protocolo anestésico. Segmentos del colon fueron retirados y sometidos a procesamiento histológico de rutina. Los cortes fueron teñidos con HE y técnicas histoquímicas para mucinas. El análisis morfométrico mostró la mantención de la pared total y del grosor de la túnica muscular, y reducción en el espesor de la túnica mucosa, en el número de células caliciformes, en la profundidad de las criptas y en la altura de los enterocitos y de sus núcleos, en los animales desnutridos. Los datos obtenidos sugieren que la desnutrición proteica provoca alteraciones en la morfometría intestinal del colon ascendente de ratas adultas, principalmente en tejidos de alto índice de renovación celular como la mucosa y, consecuentemente, de sus estructuras como los enterocitos, células caliciformes y criptas.

PALABRAS CLAVE: Dieta hipoproteica; Intestino; Pared intestinal.

\section{REFERENCES}

Araújo, E. J. A.; Sant'Ana, D. M. G.; Molinari, S. L. \& Miranda Neto, M. H. Effect of protein and vitamin B deficiency on the morphoquantitative aspects of the myenteric plexus of the descending colon of adults rats. Arq. Neuropsiquiatr., 61:226-33, 2003.

Araújo, E. J. A.; Sant'Ana, D. M. G.; Molinari, S. L. \& Miranda Neto, M. H. Biometric and food consumption parameters of rats subjected to hypoproteic and hipercaloric diet. Arq. Ciêc. Vet. Zool. UNIPAR, 8 (2):131-8, 2005
Brandão, M. C. S. Análise morfoquantitativa do plexo mientérico do intestino delgado de ratos jovens submetidos à desnutrição protéica pré e pós-natal (Master's Thesis in Scinces), Instituto de Ciências Biomédicas, Universidade de São Paulo, 1998.

Brandão, M. C. S.; De Angelis, R. C.; De Souza, R. R.; Froes, L. B. \& Liberti, E. A. Effects of pre and postnatal protein energy deprivation on the myenteric plexus of the small intestine: a morphometric study in weanling rats. Nutr. Res., 75:7-15, 2003. 
Dalçik, C.; Filiz, S.; Filiz, T. M. \& Dalçik, H. Immunohistochemical analysis of neural cell adhesion molecule (N-CAM) and pan-cadherin in the small intestine of intrauterine growth-retarded newborn rats caused by maternal protein malnutrition. Acta Histochem., 105(2):183-90, 2003.

Dellmann, H. D. \& Brown, E. M. Histologia veterinária. Rio de Janeiro, Guanabara Koogan, 1982.

Deo, M. G. Cell biology of protein-calorie malnutrition. World Rev. Nutr. Diet., 32:49-95, 1978.

Fiorine, A.; Molinari, S. L.; Natali, M. R. M. \& Miranda Neto, M. H. Quantitative morphological analysis of the myenteric neurons of the ileum in rats under experimental desnutrition. Acta Scientiarum, 21:409-413, 1999.

Firmansyah, A. \& Suharyono, S. Effect of malnutrition during different periods on the small intestine of the rat. Japan. J. Med., 59:1-7, 1969.

Firmansyah, A.; Suwandito, L.; Penn, D. \& Lebenthal., E. Biochemical and morphological changes in the digestive tract of rats after prenatal and postnatal malnutrition. Am. J. Clin. Nutr., 50:261-8, 1989.

Forstner, J. F. \& Forstner, G. G. Gastrointestinal mucus. In: Johnson, L. R. ed. Physiology of the Gastrointestinal Tract. New York, NY, Raven Press, 1994. pp. 1255-83.

Lobley, G. E.; Milne, V.; Lovie, J. M., Reeds, P. J. \& Pennie, K. Whole body and tissue protein synthesis in cattle. Br. J. Nutr., 43:491-502, 1980.

McNurlan, M. A. \& Garlick, P. J. Contribution of rat liver and gastrointestinal tract to whole-body protein synthesis in the rat. Biochem J., 186:381-3, 1980.

Meilus, M.; Natali, M. R. M.; \& Miranda Neto, M. H. Study of the myenteric plexus of the ileum of rats subjected to proteic undernutrition. Rev. Chil. Anat., 16:9-14, 1998.

Montagne, L.; Piel, C. \& Lallès, J. P. Effect of diet on mucin kinetics and composition: nutrition and health implications. Nutrition Reviews, 62(3):105-114, 2004.

Natali, M. R. M. Efeitos da desnutrição protéica materna sobre a morfologia da mucosa e neurônios do plexo mientérico do duodeno de ratos. (Dissertação de mestrado em Ciências Biológicas), Maringá, 1993.
Natali, M. R. M. \& Miranda Neto, M. H. Effect of maternal proteic undernutrition on the neurons of the myenteric plexus of the duodenum of rats. Arq. Neuropsiquiatr., 54:273-9, 1996.

Natali, M. R. M.; Miranda Neto, M. H.; Balhs A. S. \& Watanabe, I. S. Effects of maternal protein malnutrition on the duodenal mucous layer of rats. Braz. J. Morphol. Sci., 12:71-6, 1995.

Natali, M. R. M.; Miranda Neto, M. H. \& Orsi, A. M. Effect of hypoproteic diet supply on adult Wistar on adult rats (Rattus Norvegicus). Acta Scientiarum, 22:567-71, 2000.

Natali, M. R. M.; Molinari, S. L.; Valentini, L. C. \& Miranda Neto, M. H. Morphoquantitative evaluation of the duodenal myenteric neuronal population in rats fed with hypoproteic ration. Biocell, 29:39-46, 2005.

Pachaly J. R.; Sant'Ana, D. M. G.; Araujo, E. J. A.; Ciffoni, E. M. G. \& Acco, A. Anestesia of Wistar rats (Rattus norvegicus) with allometrically scaled dose of Ketamine, Xylazine, Acepromazine and Atropine preliminary report. Arq. Ciênc.Vet. Zool. UNIPAR, 6(2):195, 2003.

Pires, A. L. G.; Da Silveira, T. R.; \& Da Silva V. D. Estudo morfométrico e estereológico digital da mucosa do intestino delgado de crianças eutróficas e desnutridas com diarréia persistente. J. Pediatr., 79(4):329-36, 2003.

Rhodes, J. M. Colonic mucus and mucosal glycoproteins: the key to colitis and cancer? Gut, 30:1660-6, 1989.

Rodrigues, M. A. M.; De Camargo, J. L. V.; Coelho, K. I. R.; Montenegro, M. R. G.; Angeline, A. Y. O. \& Burini R. C. Morphometric study of the small intestinal in young, adult, and old rats submitted to protein deficiency and rehabilitation. Gut, 26:816$21,1985$.

Sant'Ana, D. M. G.; Miranda Neto, M. H.; Souza, R. R. \& Molinari, S. L. Morphological and quantitative study of the myenteric plexus of the ascending colon of subjected to proteic desnutrition. Arq. Neuropsiquiatr., 55:687-95, 1997.

Sant'Ana, D. M. G., Molinari, S. L. \& Miranda Neto, M. H. Effects of protein and vitamin B deficiency on blod parameters and myenteric neurons of the colon of rats. Arq. Neuropsiquiatr., 59:493-498, 2001. 
Schoffen, J. P. F.; Soares, A.; De Freitas, P.; Buttow, N. C. \& Natali, M. R. M. Effects of a hypoproteic diet on myosin- $\mathrm{V}$ immunostained myenteric neurons and the proximal colon wall of aging rats. Autonomic Neuroscience: Basic and Clinical, 122:77-83, 2005.

Smith, A. C. \& Podolsky, D. K. Colonic mucin glycoproteins in health and disease. Clin. Gastroenterol., 15:815-37, 1986.

Takano, J. Intestinal changes in protein-deficient rats. Exp. Mol. Pathol., 3:224-31, 1964.

Torrejais, M. M.; Natali, M. R. M.; Conegero, C. I. \& Miranda Neto, M. H. Effects of proteic malnutrition after breast-feeding on the morphology if the intestinal wall and myenteric neurons of the ileum of rats. Rev. Unimar, 17(2):315-27, 1995.

Turck, D.; Feste, A. S. \& Lifschitz, C. H. Age and diet affect the composition of porcine colonic mucins. Pediatr. Res., 33:564-7, 1993.

Viteri, F. E. \& Schneider, M. D. Gastrointestinal alterations in protein-calorie malnutrition. Sym. Gastr. Phys, 58(6):1487-505, 1974.

Waterlow, C. J. Malnutrition proteico-energetica. Washington, OPS, 1996.

Younoszai, M. K.; \& Ranshaw, J. Gastrointestinal growth in the fetus and suckling rat pups: effects of maternal dietary protein. J. Nutr., 103:454-61, 1973.

Zanim, S. T. M.; Molinari, S. L.; Sant'Ana, D. M. G. \& Miranda Neto, M. H. Neurônios NADH-diaforase positivo do jejuno de ratos adultos (Rattus norvegicus) desnutridos. Arq. Neuropsiquiatr., 61(3):650-3, 2003.
Correspondence to:

Dra. Débora de Mello Gonçales Sant'Ana

Universidade Paranaense - UNIPAR

ZIP CODE: 87.501.000

Umuarama, Paraná

BRAZIL

Email: debora@unipar.br

Received: 03-10-2007

Accepted: 17-11-2007 
